\title{
Association of Ophiostoma novo-ulmi with Scolytus schevyrewi (Scolytidae) in Colorado
}

\author{
W. R. Jacobi and R. D. Koski, Department of Bioagricultural Sciences and Pest Management, Colorado State Uni- \\ versity, Fort Collins 80523; T. C. Harrington, Department of Plant Pathology, Iowa State University, Ames 50011; \\ and J. J. Witcosky, U.S. Department of Agriculture, Forest Service, Forest Health Management, Lakewood Service \\ Center, Lakewood, CO 80225
}

\begin{abstract}
Jacobi, W. R., Koski, R. D., Harrington, T. C., and Witcosky, J. J. 2007. Association of Ophiostoma novo-ulmi with Scolytus schevyrewi (Scolytidae) in Colorado. Plant Dis. 91:245-247.

The smaller European elm bark beetle, Scolytus multistriatus, has been the primary vector of the Dutch elm disease fungus, Ophiostoma novo-ulmi, in elm trees in Colorado since 1948. An exotic from Asia, the banded elm bark beetle, Scolytus schevyrewi, was found in Siberian elm, Ulmus pumila, in Colorado in April of 2003; this was the first report of S. schevyrewi in North America. S. schevyrewi is now found throughout much of Colorado and in at least 21 other states. The similarities in breeding and feeding habits between $S$. schevyrewi and $S$. multistriatus have raised concerns about the ability of $S$. schevyrewi to serve as a vector for $O$. novo-ulmi. The objective of this preliminary study was to determine if $O$. novo-ulmi could be isolated from adult S. schevyrewi emerging from diseased elm trees. S. schevyrewi and S. multistriatus were allowed to infest diseased stem segments of American elm, Ulmus americana. The infested stem segments were caged and isolations were made from the adult brood that emerged. O. novo-ulmi was isolated from most of the adults of both beetle species, showing that $S$. schevyrewi could acquire the pathogen as effectively as $S$. multistriatus. Future studies are needed to determine if $S$. schevyrewi can effectively transmit the pathogen to healthy trees.
\end{abstract}

Dutch elm disease (DED) is a vascular wilt disease of elms, Ulmus spp., incited by the exotic fungi Ophiostoma ulmi and Ophiostoma novo-ulmi $(2,7,18,19)$. The originally introduced species $O$. ulmi has been largely replaced by the more aggressive $O$. novo-ulmi in the United States $(3,4,15)$. The pathogens are commonly spread from tree to tree by root grafts and also by elm bark beetles (Coleoptera: Scolytidae) (17-19,22). In North America, Hylurgopinus rufipes Eich., the native elm bark beetle, and Scolytus multistriatus Marsham., the smaller European elm bark beetle, are the two known vectors of the DED fungi in eastern North America $(1,19)$. Since the first confirmed report of DED in Colorado in 1948 (20), the only known vector of the DED pathogens is the smaller European elm bark beetle $(12,20)$. In regions where both $S$. multistriatus and $H$. rufipes are present in eastern North America, the former is considered the more efficient vector (19). However, S. multistriatus does not over-

Corresponding author: William Jacobi E-mail: William.Jacobi@ColoState.EDU

Accepted for publication 6 September 2006.

DOI: 10.1094/ PDIS-91-3-0245

This article is in the public domain and not copyrightable. It may be freely reprinted with customary crediting of the source. The American Phytopathological Society, 2007. winter well in cold climates, and H. rufipes is the principal vector in the northern parts of eastern North America $(1,19)$.

Scolytus schevyrewi Semenov, the banded elm bark beetle, is native to northern Chinese provinces, as well as Korea, Mongolia, Russia, Kazakhstan, Uzbekistan, Kyrgyzstan, Turkmenistan, and Tajikistan (14). The banded elm beetle was first collected in North America in April 2003 in Aurora, CO, from drought-stressed Ulmus pumila (Siberian elm) (14). By the spring of 2005, S. schevyrewi had been found in Arizona, California, Colorado, Idaho, Illinois, Indiana, Kansas, Nebraska, Nevada, New Mexico, Maryland, Michigan, Minnesota, Montana, Oklahoma, Oregon, South Dakota, Utah, and Wyoming (13). The banded elm bark beetle has not been reported from either Canada or Mexico. In its native range on the Asian continent, $S$. schevyrewi is recorded on Ulmus, Prunus, Salix, Eleaganus, and Caragana species. In the United States, $S$. schevyrewi has only been collected from four Ulmus species: $U$. americana, $U$. procera, U. pumila, and U. thomasii (14).

The role of $S$. multistriatus in the spread of DED in North America has been studied and documented since the 1940s $(6,16,17)$. The similarities in biology between $S$. schevyrewi and $S$. multistriatus warranted studies to determine the ability and efficiency of $S$. schevyrewi as a vector. Thus, the objective of this study was to determine if $O$. novo-ulmi could be acquired by adult
S. schevyrewi. If the fungus is acquired by $S$. schevyrewi, this would warrant additional studies to determine the effectiveness and efficiency of $S$. schevyrewi as a vector.

\section{MATERIALS AND METHODS}

Stem sections of DED-symptomatic $U$. americana trees in Colorado were exposed to natural populations of elm bark beetles and placed in rearing cages. Isolation attempts were made from the emerging brood using two techniques, one employed at Iowa State University (ISU) in Ames and another at Colorado State University (CSU) in Fort Collins.

Beetle sources. Stem segments from three DED-afflicted American elm ( $U$. americana) trees were removed from landscapes in Colorado Springs (two sites) and Denver in July 2004. At the time of their removal, each tree had symptoms of DED but had no evidence of infestation by bark beetles. The stem segments from the diseased trees were moved to a location at the Denver Federal Center, where S. schevyrewi and $S$. multistriatus were known to be present. After 2 to 4 weeks of exposure to natural bark beetle attack (5), the stem segments were cut into 0.3 - to $0.6-\mathrm{m}$ bolts and placed in rearing cages located at a U.S.D.A. Forest Service lab in Lakewood, $\mathrm{CO}$, or at CSU. Adult beetles from the brood that emerged were periodically collected from the rearing cages, killed by crushing the beetle, identified to species by their distinguishing elytra and sternite spine shape (11), placed individually into a sterile gelatin capsule, and stored at $4{ }^{\circ} \mathrm{C}$.

Isolations from beetles at ISU. Crushed beetles collected from stem segments at the U.S.D.A. Forest Service lab were shipped on ice overnight to ISU. Five batches of beetles were shipped between 28 September and 26 October. Upon arrival at ISU, the beetles were stored at $4^{\circ} \mathrm{C}$ until plating, generally within $72 \mathrm{~h}$ after shipping. Each beetle was cut into quarters (head, prothorax, the rest of the thorax, and abdomen), and each quarter was plated in cycloheximidestreptomycin-malt agar (CSMA) (1.5\% malt extract, $2.0 \%$ agar, 100 ppm streptomycin sulfate, and 500 ppm cycloheximide), which is semi-selective for species of Ophiostoma (8). The petri plates were incubated at room temperature (20 to $23^{\circ} \mathrm{C}$ ) for up to 3 weeks and examined 
periodically for colonies emanating from the beetle parts.

Isolation of fungi from beetles at CSU. Beetles collected from rearing cages in Fort Collins were stored individually in gelatin capsules at $2{ }^{\circ} \mathrm{C}$ and processed an average of 15 days later. The beetles were identified, crushed, and placed into amended elm sapwood agar (CSESA) (3.0\% agar, $2.5 \%$ elm sawdust, $100 \mathrm{ppm}$ streptomycin sulfate, and $200 \mathrm{ppm}$ cycloheximide). Plates were incubated at 18 to $23^{\circ} \mathrm{C}$ for up to 4 weeks and examined periodically with a dissecting microscope for the presence of the synnemal state of $O$. novo-ulmi.

O. novo-ulmi in elm stems. To verify the presence of $O$. novo-ulmi in each of the three trees, disks ( 3 to $9 \mathrm{~cm}$ thick) were removed from each of 49 stem segments obtained from the three trees and kept in plastic bags at $2^{\circ} \mathrm{C}$ for 1 to 5 days. Bark was removed from each disk, and 16 wood (xylem) chips underneath the bark were removed from four locations around the disk and placed four to a plate in CSMA medium $(1.5 \%$ malt extract, $2.0 \%$ agar, $100 \mathrm{ppm}$ streptomycin sulfate, and 200 ppm cycloheximide). Plated wood chips were incubated at 18 to $23^{\circ} \mathrm{C}$ for up to 2 weeks and examined periodically for the presence of the synnema.

\section{RESULTS}

Beetle emergence from stem segments at CSU. All exposed stem segments from diseased trees contained brood of both $S$. schevyrewi and S. multistriatus, but the predominant insect species varied from tree to tree. Beetles were collected from caged tree stem segments for 8 to 16 weeks during August to November, depending on tree number (Fig. 1). Most beetles emerged 10 to 13 weeks after logs were placed into rearing cages. Very few beetles emerged from segments taken from tree two (Fig. 1). Ninety-eight percent of the Scolytus that emerged from the caged stem segments were S. schevyrewi and $2 \%$ were $S$. multistriatus.

Isolation of $O$. novo-ulmi from beetles. An apparent Ophiostoma species was isolated from most of the plated beetles. The characteristic Sporothrix state was noted in isolations on CSMA medium, and a synnemal state (Pesotum sp.) was produced on plates containing the elm sawdust medium. At ISU, select colonies suspected to be Ophiostoma species were transferred to CSMA plates and observed to form white, fast-growing cultures (average radial growth rate of $3.2 \mathrm{~mm} /$ day) with concentric rings of heavy Sporothrix sporulation, which is typical for O. novo-ulmi. The absence of the uniform powdery phenotype also suggested that the fungus was $O$. novo-ulmi subsp. americana (4). All of the subcultured colonies had the same mycelial morphology and growth rate. One such colony from each of the three trees was used for DNA sequencing (9). The internal transcribed spacer region (ITS) of the rDNA was amplified with the primers ITS1-F and ITS-4, and the product was sequenced with the same primers at the DNA Sequencing and Synthesis Facility at Iowa State University. The sequences of the three isolates were $100 \%$ identical to each other and to other sequences of $O$. novo-ulmi previously submitted to GenBank (National Center for Biotechnology Information) (9). At CSU, conidial masses from selected synnema were transferred onto CSMA and observed to form white, fast-growing cultures with concentric rings of heavy Sporothrix sporulation, which is typical for O. novo-ulmi. All of the subcultured colonies had the same mycelial morphology and growth rate.

Of the Scolytus adults plated at ISU, $O$. novo-ulmi was isolated from $84 \%$ of adult

Table 1. Isolation of Ophiostoma novo-ulmi from adult Scolytus schevyrewi and S. multistriatus insects reared from three Ulmus americana trees

\begin{tabular}{lcccccc}
\hline & & \multicolumn{2}{c}{ S. schevyrewi } & & \multicolumn{2}{c}{ S. multistriatus } \\
\cline { 3 - 4 } \cline { 6 - 7 } Location $^{\mathbf{a}}$ & Tree $^{\mathbf{b}}$ & Number & Percent positive & & Number & Percent positive \\
\hline ISU & One & 23 & 8.7 & & 0 & 0.0 \\
& Two & 233 & 91.0 & & 71 & 91.5 \\
& Three & 32 & 84.4 & & 19 & 68.4 \\
& Totals & 288 & 83.7 & & 90 & 86.7 \\
CSU & One & 440 & 30.9 & & 4 & 0.0 \\
& Two & 52 & 63.5 & & 3 & 66.7 \\
& Three & 367 & 44.1 & & 12 & 58.3 \\
& Totals & 859 & 46.2 & & 19 & 41.7 \\
\hline
\end{tabular}

${ }^{\text {a }}$ Location of isolation attempts: ISU = Iowa State University, CSU = Colorado State University.

${ }^{\mathrm{b}}$ Three Dutch elm disease-afflicted American elm (Ulmus americana) trees removed from landscapes in Colorado Springs, and Denver, CO. Duplicate stem segments were placed in rearing cages in Denver, Colorado (ISU) and in Fort Collins, Colorado (CSU).

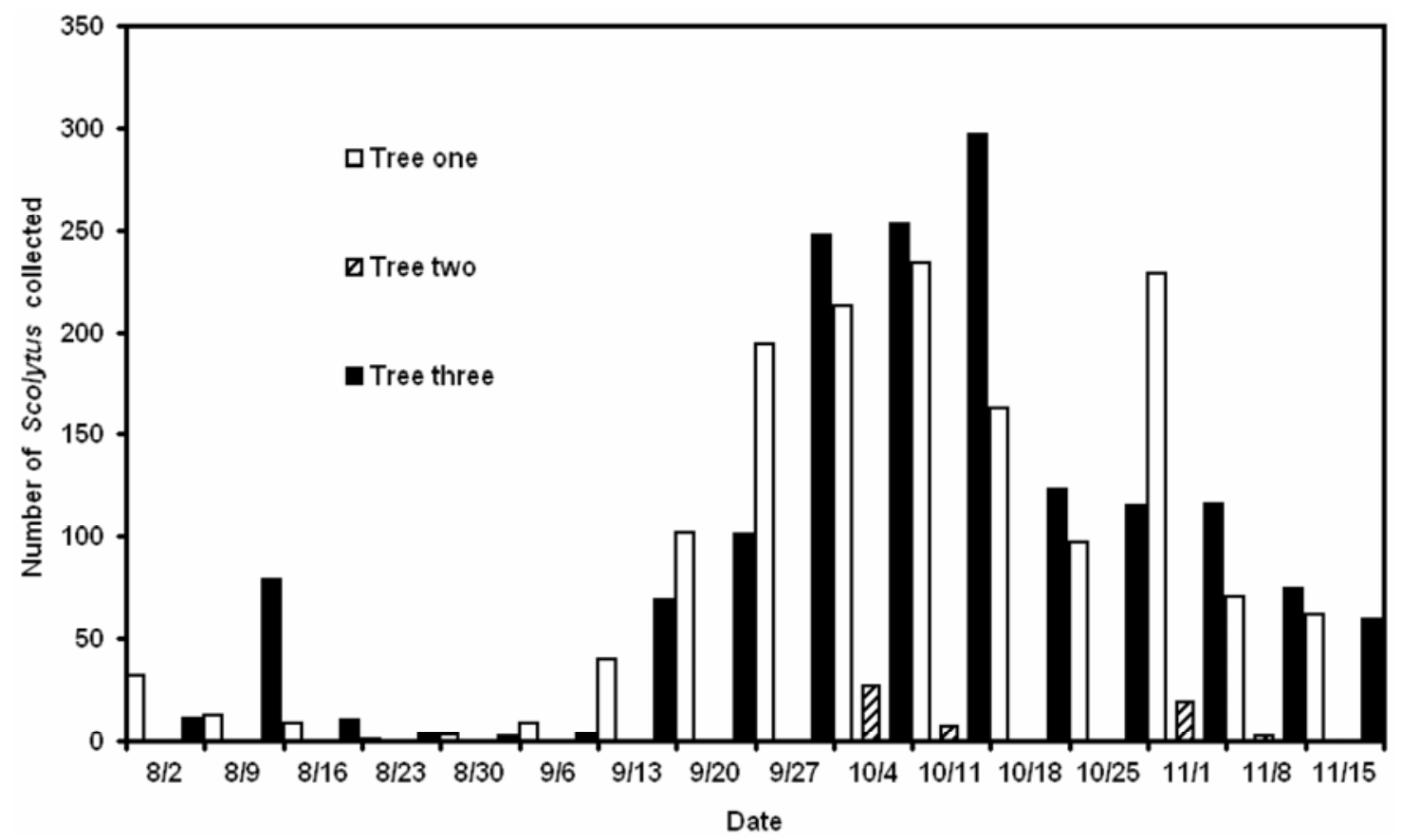

Fig. 1. Total Scolytus multistriatus and S. schevyrewi brood emergence from elm logs in rearing cages at Fort Collins, CO, 2004. 
S. schevyrewi and $87 \%$ of adult $S$. multistriatus (Table 1). Only S. schevyrewi was reared from tree one, and $O$. novo$u l m i$ was isolated from only 2 of these 23 beetles. In contrast, O. novo-ulmi was isolated from 91 and $84 \%$ of S. schevyrewi adults from trees two and three, respectively (Table 1). At CSU, isolation of $O$. novo-ulmi from emerged $S$. schevyrewi adults ranged from 31 to $64 \%$ (Table 1). The greatest percent isolation of the pathogen from $S$. schevyrewi was from tree two. Of the Scolytus adults plated at CSU, $O$. novo-ulmi was isolated from $46 \%$ of the $S$. schevyrewi plated and from $42 \%$ of the $S$. multistriatus plated (Table 1).

Recovery of $O$. novo-ulmi from stem segments at CSU. Based on isolations from wood chips, all three of the trees utilized in this study were infected with $O$. novo-ulmi. O. novo-ulmi was isolated from 93, 100, and 100\%, respectively, from trees one, two, and three.

\section{DISCUSSION}

While stem segments from all three trees were infested with both $S$. schevyrewi and $S$. multistriatus, the number of $S$. schevyrewi exceeded the number of $S$. multistriatus in all three trees. The variation in the number of beetles used for isolation from a particular tree at CSU and ISU was the result of collecting beetles from different stem segments caged in Lakewood or Fort Collins, CO. Most of the sampled disks from the segments were well-colonized by O. novo-ulmi, but there was some variation. The lower frequency of isolation of O. novo-ulmi from some tree segments may be due to unequal distribution of the pathogen in the trees. This likely resulted in the lower percentage isolation of $O$. novo-ulmi from the Scolytus adults reared from segments taken from tree one.

O. novo-ulmi was isolated from 9 to $91 \%$ of the $S$. schevyrewi adults and 0 to $92 \%$ of the S. multistriatus adults. The higher isolation rate at ISU versus CSU may be due to the quartering of the beetles before plating at ISU and the higher concentration of cycloheximide used in CSMA at ISU. The pathogen was recovered from $S$. schevyrewi in percentages comparable to that from the most important vector $(S$. multistriatus) in North America. The high percentage of recovery of $O$. novo-ulmi from $S$. schevyrewi suggests that it has the potential to be an important vector of the DED fungus. However, our results should be considered preliminary because the attacking bark beetles were infesting stem segments rather than standing trees, and trees from only three sites were sampled. Nonetheless, it is clear that $S$. schevyrewi is capable of acquiring O. novo-ulmi in high percentages from naturally diseased trees.

Pathogen recovery from plated adults of the two Scolytus species (41 to $84 \%$ ) is in line with the earlier findings of Parker et al. $(16,17)$, who successfully isolated $O$. ulmi from $76 \%$ of plated S. multistriatus surface washings and $14 \%$ from plated $S$. multistriatus intestinal tracts. Of the $S$. multistriatus beetles that emerged from infested elm trees in Spain, 35 to $64 \%$ were contaminated with aggressive and nonaggressive strains of $O$. ulmi (now recognized as $O$. novo-ulmi and $O$. ulmi, respectively) (21). Spore loads (number of spores on beetles) were not assessed in our study, but previous work in Spain indicated a large variation in spore loads within and among Scolytus species in Europe. Thus, further studies are needed to compare spore loads on S. schevyrewi and S. multistriatus in the United States to compare their effectiveness as vectors of $O$. novo-ulmi.

The biology of $S$. schevyrewi, including breeding in stressed (diseased) elm trees (14), pupation in the outer bark, and maturation feeding in twigs, is very similar to that of $S$. multistriatus, suggesting that $S$. schevyrewi could serve as an effective vector of $O$. novo-ulmi $(10,14)$. Future studies are needed to determine if $S$. schevyrewi can effectively introduce the pathogen into an infection court and establish the fungus in a living elm tree. The timing of maturation feeding by the newly emerged adults, wound location, depth of wounds, amount of inoculum transferred by beetles, and the susceptibility of trees during the season need to be assessed. If $S$. schevyrewi can effectively transmit the fungus and it continues to spread and dominate over $S$. multistriatus in North America, then it could become the principal vector of $O$. novo-ulmi. The native range of $S$. schevyrewi in Asia suggests that this species tolerates cold winter temperatures much better than does $S$. multistriatus, so the newly introduced $S$. schevyrewi could be especially important in colder climates $(10,14)$.

\section{ACKNOWLEDGMENTS}

We acknowledge the assistance of Jose Negron, USDA Forest Service, Rocky Mt. Research Station, Melodie Moss, Colorado State University, Becky Lamphear, City of Colorado Springs, and Doug Schoch, City of Denver, for assistance in this study. USDA Forest Service, Forest Health Management, Region 2 and the Colorado Agricultural Experiment Station provided funding. Daniel Thorpe assisted with isolations at Iowa State University.

\section{LITERATURE CITED}

1. Anderson, P. L., and Holliday, N. J. 2003. Distribution and survival of overwintering adults of the Dutch elm disease vector, Hylurgopinus rufipes (Coleoptera: Scolytidae), in American elm trees in Manitoba. Agric. For. Entomol. 5:137-144.

2. Brasier, C. M. 1991. Ophiostoma novo-ulmi sp. nov., causative agent of current Dutch elm disease pandemics. Mycopathologia 115:151-161.

3. Brasier, C. M. 1996. Low genetic diversity of the Ophiostoma novo-ulmi population in North America. Mycologia 88:951-964.

4. Brasier, C. M., and Kirk, S. A. 2000. Survival of clones of NAN Ophiostoma novo-ulmi around its probable center of appearance in North America. Mycol. Res. 104:1322-1332.
5. Byers, J. A., Svlhra, P., and Koehler, C. S. 1980. Attraction of elm bark beetles to cut limbs on elm. J. Arboric. 6:245-246.

6. Collins, C. W., Buchanan, W. D., Whitten, R. R., and Hoffman, C. H. 1936. Bark beetles and other possible insect vectors of the Dutch elm disease Ceratostomella ulmi (Schwarz) Buisman. J. Econ. Entomol. 29:169-176.

7. Dunn, C. P., ed. 2000. The Elms: Breeding, Conservation, and Disease Management. Kluwer Academic Publishers, Norwell, MA.

8. Harrington, T. C. 1992. Leptographium. Pages 129-133 in: Methods for Research on Soilborne Phytopathogenic Fungi. L. L. Singleton, J. D. Mihail, and C. M. Rush, eds. American Phytopathological Society, St. Paul, MN

9. Harrington, T. C., McNew, D. M., Steimel, J. Hofstra, D., and Farrell, R. 2001. Phylogeny and taxonomy of the Ophiostoma piceae complex and the Dutch elm disease fungi. Mycologia 93:110-135.

10. Jin-Lin, S., and Fang, C. 1990. Breeding behavior of the bark beetle Scolytus schevyrewi Semenov (Col., Scolytidae) in Ulmus pumila. J. Appl. Entomol. 109:528-530.

11. LaBonte, J. R., Rabaglia, R. J., and Hoebeke, E. R. 2003. A screening aid for the identification of the banded elm bark beetle, Scolytus schevyrewi Semenov. Center for Environmental and Regulatory Information System (CERIS), Purdue University. Online publication.

12. Laut, J. G., Helburg, L. B., and Schomaker, M. E. 1973. Dutch elm disease in Colorado 1972. Plant Dis. Rep. 57:511-513.

13. National Agricultural Pest Information System (NAPIS). 2005. Center for Environmental and Regulatory Information System (CERIS), Purdue University, West Lafayette, IN.

14. Negron, J. F., Witcosky, J. J., Cain, R. J., LaBonte, J. R., Duerr, D. A., II, McElwey, S. J., Lee, J. C., and Seybold, S. J. 2005. The banded elm bark beetle: A new threat to elms in North America. Am. Entomol. 51:84-94.

15. Paoletti, M., Buck, K. W., and Brasier, C. M. 2006. Selective acquisition of novel mating type and vegetative incompatibility genes via interspecies gene transfer in the globally invading eukaryote Ophiostoma novo-ulmi. Mol. Ecol. 15:249-262.

16. Parker, K. G., Collins, D. L., Tyler, L. J., Connola, D. P., Ozard, W. E., and Dietrich, H. 1947. The Dutch Elm Disease: Association of Ceratostomella ulmi with Scolytus multistriatus, Its Advance into New Areas, Methods of Determining Its Distribution and Control of the Disease. Cornell University Agric. Exp. Stn. Mem. 275, November 1947

17. Parker, K. G., Readio, P. A., Tayler, L. J., and Collins, D. L. 1941. Transmission of the Dutch elm disease pathogen by Scolytus multistriatus and the development of infection. Phytopathology 31:657-663.

18. Sinclair, W. A., and Campana, R. J., eds. 1978. Dutch Elm Disease: Perspectives After 60 years. Northeast Regional Research Publication, Agriculture 8(5). Cornell University Agricultural Experiment Station, Ithaca, NY.

19. Stipes, R. J., and Campana, R. J., eds. 1981. Compendium of Elm Disease. American Phytopathological Society, St. Paul, MN.

20. Thomas, W. D., Jr., List, G. M., Michaelson, M. E., and Buchanan, W. D. 1948. Dutch elm disease in Colorado. Plant Dis. Rep. 32:317.

21. Webber, J. F. 1990. Relative effectiveness of Scolytus scolytus, S. multistriatus, and S. kirschi as vectors of Dutch elm disease. Eur. J. For. Pathol. 20:184-192.

22. Webber, J. F., and Gibbs, J. N. 1989. Insect dissemination of fungal plant pathogens of trees. Pages 161-193 in: Insect-Fungus Interactions. N. Wilding, N. M. Collins, P. M Hammond, and J. F. Webber, eds. Academic Press, London. 